\title{
TINDAK BAHASA GURU DALAM PEMBELAJARAN BAHASA INDONESIA DI KELAS VIII SMPN 7 BANJARMASIN
}

\section{THE LANGUAGE ACTS OF THE TEACHER IN LEARNING INDONESIAN IN CLASS VIII OF THE 7 PUBLIC HIGH SCHOOL IN BANJARMASIN}

\author{
Khairunnisa; Moh. Fatah Yasin; Rusma Noortyani \\ Program Studi Pendidikan Bahasa dan Sastra Indonesia \\ FKIP Universitas Lambung Mangkurat \\ icakhairunnisa5@gmail.com
}

\begin{abstract}
Abstrak
Penelitian ini bertujuan untuk mendeskripsikan atau menggambarkan tindak bahasa guru dalam pembelajaran bahasa Indonesia di kelas VIII SMPN 7 Banjarmasin dengan merekam awal pembelajaran sampai akhir. Jenis Penelitian yang digunakan dalam penelitian ini adalah penelitian kualitatif dengan menggunakan metode deskriptif. Hasil penelitian ini membuktikan bahwa tindak bahasa guru dalam pembelajaran bahasa Indonesia di kelas VIII SMPN 7 Banjarmasin terdapat tiga tindakan ilokusi, seperti: tindak asertif (tindak pemberitahuan, tindak mengucap salam, tindak menjelaskan, tindak menyatakan contoh, tindak membual, tindak menunjuk), tindak direktif (tindak bertanya, tindak ajakan, tindak suruhan, tindak mengulang, tindak perintah, tindak mengizinkan, tindak nasihat), dan tindak ekspresif (tindak menyalahkan).
\end{abstract}

Kata kunci: Tindak bahasa, guru, pembelajaran.

\begin{abstract}
This study aims to describe or describe the language acts of teachers in learning Indonesian in class VIII of SMPN 7 Banjarmasin by recording the beginning of learning until the end. The type of research used in this study is qualitative research using descriptive methods. The result of this study prove that the language acts of the teacher in learning Indonesian in class VIII of SMPN 7 Banjarmasin there are three illocutionary actions, such as: assertive action (follow notification, act of greeting, act of explaining, act of expressing example, act of boasting, act of pointing), act directive (act of questioning, act of invitation, act of submission, act of repetition, action of command, act of permission, act of counsel), and act of expressive (act of blame).
\end{abstract}

Keyword: language action, teacher, learning 


\section{Pendahuluan}

Belajar menggunakan bahasa Indonesia sangat baik untuk keperluan berkomunikasi dalam proses belajar mengajar. Sehubungan dengan itu, melalui penelitian ini akan dikaji mengenai pemakaian tindak bahasa guru dalam pembelajaran bahasa Indonesia di kelas VIII-D.

Peneliti mengadakan penelitian di SMP Negeri 7 Banjarmasin karena sekolah ini merupakan sekolah yang mempunyai akreditasi A dan akan menjadi sekolah rujukan yang memiliki banyak terobosan untuk mendapatkan peserta didik yang unggul dan berprestasi. Sebelum adanya sistem zona sekolah SMPN 7 hanya menerima peserta didik yang hanya memiliki nilai tertinggi. Dalam dua tahun menggunakan sistem zona banyak peserta didik yang memiliki nilai rendah. Sekolah berusaha untuk merubah kebiasaan peserta didik yang malas dalam belajar dan merubah pola pikir peserta didik agar bisa aktif dalam proses belajar mengajar, agar bisa menjadi sekolah rujukan kata seorang guru kelas VIII yang bernama Ibu Rakhmalina, S.Pd. dan Wakasek II Toni Maxitop, M.Pd.

$$
\text { Banyak kegiatan yang }
$$

dilakukan di pagi hari sebelum peserta didik melakukan proses belajar mengajar. Kegiatan ini dilakukan agar peserta didik terbiasa membaca buku dan memiliki banyak pengetahuan dari buku yang dibaca. Sekolah SMP juga melatih setiap guru agar bisa terampil dalam mengajar di kelas karena kurikulum yang digunakan adalah kurikulum 2013 dan para guru harus bisa memberikan sesuatu yang berbeda dari sebelumnya. Setiap guru juga di nilai dalam mengajar di kelas oleh kepala sekolah setiap bulannya. Oleh karena itu, peneliti ingin meneliti salah satu guru Bahasa Indonesia di kelas VIII-D. Penulis memilih tempat penelitian di SMP Negeri 7 Banjarmasin, penulis bermaksud ingin mengetahui secara langsung bagaimana tindak bahasa yang digunakan oleh pendidik kepada peserta didik dalam interaksi belajar mengajar di kelas. 


\section{Metode Penelitian}

\section{Jenis Penelitian}

Jenis penelitian ini menggunakan pendekatan kualitatif yang bersifat deskriptif. Hal ini bertujuan untuk mendeskripsikan tindak bahasa guru secara langsung atau tidak langsung dalam pelajaran Bahasa Indonesia di SMPN 7 Banjarmasin. Maka dari itu, data yang dihasilkan peneliti akan dideskripsikan secara benar tanpa menggunakan hitungan maupun angka-angka, selanjutnya data yang dihasilkan akan dianalisis oleh peneliti dengan teknik kualitatif.

\section{Data dan Sumber Data}

Penelitian dalam data ini berupa tindak bahasa guru di ruang kelas saat mengajar pelajaran bahasa Indonesia. Tindak bahasa berupa tindak bahasa lokusi, tindak bahasa ilokusi, dan tindak bahasa perlokusi. Tuturan tersebut dihasilkan oleh guru dan peserta didik sewaktu berdialog, berinteraksi, dan berkomunikasi saat pembelajaran awal di kelas. Sumber data dalam penelitian ini berupa tindak bahasa lokusi, tindak bahasa ilokusi, dan tindak bahasa perlokusi yang diujarkan guru dalam pembelajaran bahasa Indonesia di kelas sebagai bahan kajian untuk mengetahui tindak bahasa yang terdapat dalam penelitian.

\section{Teknik Pengumpulan Data}

Peneliti menggunakan teknik pengumpulan data, berupa (1) teknik observasi atau pengamatan non partisipan, peneliti hanya menyimak tanpa harus melibatkan diri untuk ikut dalam pembelajaran berlangsung dan peneliti hanya sebagai pengamat dalam jalannya proses pembelajaran di kelas, (2) teknik rekam merupakan teknik untuk merekam jalannya proses pembelajaran dengan menggunakan handpone atau kamera yang bertujuan untuk merekam tuturan yang disampaikan penutur, (3) dokumen untuk melengkapi data berupa RPP guru untuk mengajar, (4) Mencatat tuturan dalam berkomunikasi berupa transkip tuturan guru dalam kelas.

\section{Teknik Analisis Data}

Teknik analisis data menggunakan teknik analisis interaktif yang terdiri dari pegumpulan data, penyajian data, reduksi data, dan penarikan kesimpulan. Sedangkan 
prosedur penelitian yang dilakukan terdiri dari beberapa tahap yaitu pengumpulan data, proses penyeleksian data, proses menganalisis data yang sudah diseleksi dan terakhir membuat laporan penelitian. Adapun tabel penelitian "Jenis-jenis tindak bahasa guru dalam pembelajaran bahasa Indonesia di kelas VIII-D SMP Negeri 7 Banjarmasin.

\section{Hasil dan Pembahasan}

Penelitian hasil ini disajikan dengan mendeskripsikan jenis-jenis tindak bahasa guru pada pembelajaran bahasa Indonesia di SMP 7 Banjarmasin tahun ajaran 2018/2019. Berdasarkan hasil analisis penelitian, peneliti menemukan beberapa jenis tindak bahasa dari tindak bahasa Ilokusi yang digunakan dalam tuturan guru pada pembelajaran Bahasa Indonesia, yaitu tindak pemberitahuan, tindak mengucap salam, tindak bertanya, tindak ajakan, tindak suruhan, tindak mengulang, tindak menjelaskan, tindak perintah, tindak menyatakan contoh, tindak membual, tindak mengizinkan, tindak menunjuk, tindak nasihat, dan tindak menyalahkan. Dalam beberapa jenis tindakan yang dituturkan oleh guru, tindakan tersebut masuk ke dalam tindakan Ilokusi, yaitu asertif, direktif, dan ekspresif.

Berikut paparan hasil penelitian terhadap jenis-jenis tindak bahasa yang terkandung dari tuturan guru pada pembelajaran Bahasa Indonesia di SMP Negeri 7 Banjarmasin tahun ajaran 2018/2019.

a) Tindak Pemberitahuan

Tindak bahasa asertif pemberitahuan dapat ditemukan 5 tuturan. Contoh jenis tindak bahasa asertif pemberitahuan sebagai berikut.

(1) Pertama, menceritakan kembali isi teks ulasan tentang kualitas karya baik itu puisi maupun film.

Pada contoh (1) di atas, Guru memberitahukan kepada peserta didik mengenai pelajaran yang akan dipelajari pada saat itu. Tindak bahasa contoh (1) di atas termasuk tindak bahasa ilokusi asertif yang ditandai dengan pem-beritahuan 
mengenai pembelajaran yang akan dipelajari.

b) Mengucapkan Salam

Tindak bahasa direktif mengucapkan salam dapat ditemukan 2 tuturan. Contoh jenis tindak bahasa direktif mengucapkan salam sebagai berikut.

(6) Wassalamualaikum Warahmatullahi Wabarakatuh.

Pada contoh (6) di atas, Guru mengucapkan salam ketika pembelajaran sudah berakhir kepada semua peserta didik. Tindak bahasa contoh (6) di atas termasuk ke dalam tindak bahasa ilokusi asertif yang ditandai dengan ucapan salam.

\section{c) Tindak Bertanya}

Tindak bahasa direktif bertanya dalam tindak bahasa guru dalam pembelajaran di kelas terdapat 38 tuturan. Contoh jenis tindak bahasa direktif bertanya sebagai berikut.

(8)Ada yang belum dapat soal dan lembar jawabannya?

Pada contoh (8) di atas, guru bertanya kepada setiap kelompok apakah mereka sudah mendapatkan soal beserta dengan lembar jawabannya. Para peserta didik menjawab dengan serentak kalau mereka sudah mendapatkan semuanya. Tindak bahasa contoh (8) termasuk tindak bahasa direktif bertanya yang ditandai dengan tanda tanya. Tanda tanya digunakan penutur (guru) untuk menanyakan kepada mitratutur (peserta didik) terkait dengan soal dan lembar jawaban yang dibagikan.

d) Tindak Ajakan

Tindak bahasa direktif ajakan dalam pembelajaran terdapat 3 tuturan. Contoh jenis tindak bahasa direktif ajakan sebagai berikut.

(46) Balonku ada lima, rupa-rupa warnanya Hijau, kuning, kelabu, merah muda, dan biru Meletus balon hijau "door", hatiku sangat kacau Balonku tinggal empat ku pegang erat-erat.

Pada contoh (46) di atas, guru mengajak semua peserta didik untuk bernyanyi lagu balonku agar kelas ceria dan tidak kaku. Tindak bahasa contoh (46) termasuk tindak bahasa direktif ajakan yang ditandai dengan nyanyian. Nyanyian di-gunakan 
penutur (guru) untuk mengajak kepada peserta didik agar dapat bernyanyi bersama dan mem-buat anak memperhatikan penutur (guru).

e) Tindak Suruhan

Tindak bahasa direktif suruhan mempunyai 22 tuturan. Contoh jenis tindak bahasa direktif suruhan sebagai berikut.

$$
\begin{aligned}
& \text { (49) Ya stop!!! } \quad \text { Lepas } \\
& \text { polpennya, } \\
& \text { hasilnya! }
\end{aligned}
$$

Pada contoh (49) di atas, guru menyuruh peserta didik untuk berhenti mengerjakan tugas yang penutur (guru) berikan dan menyuruh peserta didik agar mengumpulkan hasil pekerjaannya ke depan. Tindak bahasa contoh (49) termasuk tindak bahasa direktif suruhan yang ditandai dengan kata stop dan lepas polpennya, kumpul hasilnya. Kata itu digunakan penutur (guru) agar menyuruh peserta didik berhenti mengerjakan tugas.

f) Tindak Mengulang

Tindak bahasa direktif mengulang dalam tindak bahasa guru dalam pembelajaran bahasa
Indonesia di kelas terdapat 1 tuturan. Contoh jenis tindak bahasa direktif mengulang sebagai berikut.

(66) Halaman 136, iya!!

Pada contoh (66) di atas, guru mengulang kembali jawaban peserta didik mengenai pertanyaan guru yang menanyakan halaman berapa yang terkait dengan menceritakan kembali isi teks ulasan. Dalam tuturan yang digunakan guru untu memastikan halaman yang disebutkan peserta didik agar tidak salah dengar. Tindak bahasa contoh (66) termasuk tindak bahasa ilokusi direktif mengulang yang ditandai dengan kata halaman 136, iya.

g) Tindak Menjelaskan

Tindak bahasa asertif menjelaskan di kelas terdapat 18 tuturan. Contoh jenis tindak bahasa asertif menjelaskan sebagai berikut.

(67) Menceritakan kembali teks ulasan, kita bisa hari ini menjelaskan atau memahami teks ulasan yang buku novel yaitu "Surat Kecil untuk Tuhan" hari ini kita bisa menjelaskan teks ulasan berupa puisi, judulnya! 
Pada contoh (67) di atas, guru menjelaskan terkait menceritakan kembali isi teks ulasan yang sudah dibacakan oleh seorang peserta didik. Tindak bahasa contoh (67) termasuk tindak bahasa refresentatif yang ditandai dengan kata menjelaskan. Kata menjelaskan digunakan penutur (guru) untuk menyampaikan pembahasan kepada peserta didik agar dapat dipahami oleh semua peserta didik.

h) Tindak Perintah

Tindak bahasa direktif perintah dalam pembelajaran bahasa Indonesia untuk tindak bahasa di kelas terdapat 7 tuturan. Contoh jenis tindak bahasa direktif perintah sebagai berikut.

(85) Ayo ulangi apa jar ibu tadi, apa jar ibu tadi! Bagi pengulas apa?

Pada contoh (85) di atas, guru memerintah salah seorang peserta agar dapat mengulangi apa yang sudah dijelaskan oleh penutur (guru) terkait pelajaran teks ulasan. Tindak bahasa contoh (85) termasuk tindak bahasa direktif perintah yang ditandai dengan kata ulangi. Kata ulangi digunakan penutur (guru) memerintah salah satu peserta didik agar bisa menjelaskan kembali penjelasan dari penutur (guru).

i) Tindak Menyatakan Contoh Tindak bahasa asertif menyatakan contoh dalam tindak bahasa guru dalam pembelajaran bahasa Indonesia di kelas terdapat 11 tuturan. Contoh jenis tindak bahasa asertif menyatakan contoh sebagai berikut.

(94) Tangan di atas lebih baik pada tangan di bawah dan asal ngomong boleh, tangan di bawah lebih baik pada tangan di atas, itu kata siapa? Kata yang minta-minta tangan di bawah lebih baik pada tangan di atas. Kenapa? Bila anda masuk keliang lahat ada tiga malaikat, apa jawabnnya? Salah! Kamu boleh menyalahkan, salah $\mathrm{Bu}$ ! Cuma berapa?

Pada contoh (94) di atas, guru memberikan contoh kepada peserta didik mengenai maksud dan arti penting teks ulasan (mengkritik). Tindak bahasa contoh (94) termasuk tindak bahasa asertif menyatakan contoh yang ditandai dengan contoh 
seorang yang minta-minta. Kata minta-minta digunakan penutur (guru) untuk memberikan sebuah contoh mengenai orang miskin yang suka minta-minta di jalan-jalan dan kata malaikat juga diterangkan di atas agar peserta didik paham dengan cara mengulas teks ulasan.

j) Tindak Membual

Tindak bahasa asertif membual dalam tindak bahasa guru dalam pembelajaran bahasa Indonesia di kelas terdapat 1 tuturan. Contoh jenis tindak bahasa asertif membual sebagai berikut.

(105) Kalau yang bahasa bagi ceritanya tentang kita, putus cinta!

Pada contoh (105) di atas, guru membual dengan membuat hiburan dengan mengatakan putus cinta kepada peserta didik dan membuat semua tertawa. Tindak bahasa contoh (105) termasuk tindak bahasa refresentatif membual yang ditandai dengan kata putus cinta. Kata putus cinta digunakan penutur (guru) untuk membual atau bercanda dengan peserta didik agar suasana kelas tidak tegang.

\section{k) Tindak Mengizinkan}

Tindak bahasa direktif mengizinkan dalam tindak bahasa guru dalam pembelajaran bahasa Indonesia di kelas terdapat 1 tuturan. Contoh jenis tindak bahasa direktif mengizinkan sebagai berikut.

$$
\text { (106) Di buku catatan saja! }
$$

Pada contoh (106) di atas, guru mengizinkan peserta didik untuk mengerjakan tugas yang diberikan ke dalam buku catatan. Tuturan itu digunakan pada saat seorang peserta didik bertanya kepada guru terkait di mana mengerjakan tugas yang diberikan. Tindak bahasa contoh (106) termasuk tindak bahasa ilokusi direktif mengizinkan yang ditandai dengan kata di buku catatan saja. Kata itu digunakan agar peserta didik tidak salah dalam menulis tugas yang diberikan oleh guru.

1) Tindak Menunjuk

Tindak bahasa asertif menunjuk hanya terdapat 2 tuturan. Contoh jenis tindak bahasa asertif menunjuk sebagai berikut. 
(107) Yang kedua lanjut!

Pada contoh (107) di atas, guru menunjuk salah satu peserta didik untuk melanjutkan membacakan alinea kedua terkait mencari butir pokok dalam teks ulasan. Tindak bahasa contoh (107) termasuk tindak bahasa asertif menunjuk yang ditandai dengan kata yang kedua lanjut. Kata itu digunakan agar peserta didik yang ditunjuk bisa merespon dengan cepat untuk membacakan hasil selanjutnya.

m) Tindak Nasihat

Tindak bahasa direktif nasihat dalam tindak bahasa guru pembelajaran bahasa Indonesia di kelas terdapat 1 tuturan. Contoh jenis tindak bahasa direktif nasihat sebagai berikut.

(109) Jadi, kalau Abahnya tidak paham masalah IT, tolong jelaskan jangan dikatakatain. "Bah, Abah nih ketinggalan zaman" sama sekali kada nyaman. Ibu zul ketinggalan zaman, emang ketinggalan zaman.

Pada contoh (109) di atas, guru menasihati peserta didik agar tidak boleh mengatai orang tuanya kalau memang tidak paham masalah IT. Seharusnya peserta didik bisa mengajari orang tuanya kalau memang tidak paham masalah apapun. Dalam tuturan itu agar peserta didik tidak berani dengan orang tuanya dan selalu patuh dan sopan dan mau mengajari apapun ke orang tuanya. Tindak bahasa contoh (109) termasuk tindak bahasa ilokusi direktif nasihat yang di tandai dengan kata kalau Abahnya tidak paham tolong jelaskan. Kata itu digunakan agar peserta didik bisa menghormati orang tua dan tidak mengkata-katai.

n) Tindak Menyalahkan

Tindak bahasa ekspresif menyalahkan di kelas terdapat 1 tuturan. Contoh jenis tindak bahasa ekspresif menyalahkan sebagai berikut.

(110) Apa tadi kata Ibu, bisa! Nah, ya lo kada paham inya.

Pada contoh (110), guru menyalahkan salah satu peserta yang belum bisa menjawab pertanyaan dari guru karena tidak memperhatikan penjelasan dari penutur (guru). Tindak bahasa contoh (110) termasuk tindak bahasa 
ekspresif menyalahkan yang ditandai dengan kata nah, ya lo kada paham. Kata itu digunakan penutur (guru) menyalahkan salah satu peserta didik yang sibuk berbicara dengan temannya.

\section{Pembahasan}

Berdasarkan hasil penelitian mengenai tindak bahasa guru, peneliti menemukan beberapa jenis tindak bahasa yang muncul dalam bahasa guru pada pelajaran bahasa Indonesia yang meliputi tindak ilokusi. Tindak pemberitahuan sebanyak (5), tindak mengucap salam sebanyak (2), tindak bertanya sebanyak (38), tindak ajakan sebanyak (3), tindak suruhan sebanyak (17), tindak mengulang sebanyak (1), tindak menjelaskan sebanyak (18), tindak perintah sebanyak (9), tindak menyatakan contoh sebanyak (11), tindak membual sebanyak (1), tindak mengizinkan sebanyak (1), tindak menunjuk sebanyak (2), tindak nasihat (1), dan tindak menyalahkan sebanyak (1).

Berdasarkan hasil simpulan di atas dapat dipaparkan bahwa tindak bahasa yang digunakan guru berupa tindakan ilokusi yang di dalamnya banyak digunakan berupa tindak pertanyaan.

\section{Simpulan dan Saran}

\section{Simpulan}

Berdasarkan hasi analisis data dan hasil penelitian terhadap Tindak Bahasa Guru dalam Pembelajaran Bahasa Indonesia di Kelas VIII SMP Negeri 7 Banjarmasin, dapat disimpulkan bahwa dalam jenis tindak bahasa yang terdiri dari tiga jenis, yaitu: tindak lokusi, tindak ilokusi, dan tindak perlokusi. Oleh karena itu, tindak ilokusi yang terdapat di dalam hasil analisis, seperti: tindak asertif (pemberitahuan, mengucap salam, menjelaskan, menyatakan contoh, membual, dan menunjuk), tindak direktif (bertanya, ajakan, suruhan, mengulang, perintah, mengizinkan, nasihat), dan tindak ekspresif (menyalahkan).

\section{Saran}

Berdasarkan hasil penelitian dan pembahasan yang telah disajikan pada bagian sebelumnya, penulis dapat menyarankan hal-hal sebagai berikut. 
1. Seorang guru dalam proses belajar mengajar harus menggunakan tuturan yang sopan dan memberikan contoh sesuai dengan isi pelajaran jangan sampai keluar dari jalur yang diajarkan agar peserta didik dapat memahami setiap penjelasan dari penutur (guru)

2. Penelitian ini bisa dijadikan bahan untuk penelitian selanjutnya dan diharapkan dapat diteliti lebih lanjut terkait Tindak Bahasa Guru dalam Pembelajaran Bahasa Indonesia di Kelas.

\section{Daftar Pustaka}

Austin. J.L. 1975. How to Do Things With Words. Cambridge: Harvard University Press.

Darma, Y. A. 2014. Analisis Wacana Kritis dalam Multiperspektif. Bandung: PT Refika Aditama.

Leech, Geoffrey. 1993. PrinsipPrinsip Pragmatik (Terj. Oka). Jakarta: Universitas Indonesia

Nababan, P.W. J. 1987. Ilmu Pragmatik (Teori dan Penerapannya). Jakarta: Gramedia.
Rahardi, Kunjana. 2005. Pragmatik (Kesantunan Imperatif Bahasa Indonesia). Yogyakarta: Erlangga.

Rahardi, Kunjana. 2009. Sosiopragmatik. Yogyakarta: Erlangga.

Searle, J.R. 1969. Speech Acts: An Essay in The Philosophy of Language. Cambridge: Cambridge University Press.

Tarigan, Henry Guntur. 1984. Pengajaran Pragmatik. Bandung: Penerbit Angkasa.

Yule, George. 2006. Pragmatik (Terj. Jumadi). Banjarmasin: PBS FKIP Universitas Lambung Mangkurat.

Purwo, Bambang K. 1990. Pragmatik dan Pengajaran Bahasa. Yogyakarta: Kanasius.

Chaer, Abdul dan Leonie Agustina. 2010. Sosiolinguistik Perkenalan Awal. Jakarta: Rineka Cipta

Moeslichatoen R. 2004. Metode Pengajaran Di Taman KanakKanak. Jakarta: PT Asdi Mahasatya

A.M, Sardiman. 2016. Interaksi dan Motivasi Belajar Mengajar. Jakarta: PT Raja Grafindo.

Rukmana, H.F, Suryadi, \& Diani Irma. 2017. Tindak Tutur Guru 
dalam Pembelajaran Bahasa

Indonesia di Kelas VII

Tunagrahita SMPLB Dharma

Wanita Persatuan Provinsi

Bengkulu. Jurnal Korpus

(vol.1, no.1)

Yuliana, R., Rohmadi, M., Suhita, R.

2013. Daya Pragmatik Tindak
Tutur Guru dalam

Pembelajaran Bahasa

Indonesia pada Siswa Sekolah

Menengah Pertama. Jurnal

BASASTRA (vol.2, no.1). ISSN 12302-6405 